\title{
Laparoscopic management of adnexal masses: a hospital-based study
}

\author{
Somen Bhattacharjee ${ }^{1}$, Shashishankar Sharma ${ }^{2 *}$
}

${ }^{1}$ Department of Obstetrics and Gynecology, ${ }^{2}$ Department of Surgery, MGM Medical College, Indore, Madhya Pradesh, India

Received: 13 March 2018

Accepted: 15 March 2018

\section{*Correspondence:}

Dr. Shashishankar Sharma,

E-mail: drsomenmd@yahoo.com

Copyright: $($ ) the author(s), publisher and licensee Medip Academy. This is an open-access article distributed under the terms of the Creative Commons Attribution Non-Commercial License, which permits unrestricted non-commercial use, distribution, and reproduction in any medium, provided the original work is properly cited.

\begin{abstract}
Background: Laparoscopy is a widely used procedure in gynecological cases both for diagnostic and operative purposes. Laparoscopic surgery has been associated with early recovery, shorter duration of hospital stay and significant patient satisfaction. The present study is conducted to evaluate the effectiveness and safety of laparoscopy in the management of adnexal masses. Primary aim of this study is to find out the indications, intraoperative findings and the different interventions contemplated to deal with the adnexal masses.

Methods: The study period was of 7 months, from July 2017 to January 2018, in the Dept of Obstetrics and Gynecology, MGM Medical College and M.Y. Hospitals Indore, MP. During this period, 63 patients underwent laparoscopy for various adnexal masses. Cases were critically analyzed and results were presented.

Results: Most of the patients were from the age-group 25-30 yrs. Most common indication was ovarian tumor of varied pathology. Most common surgical procedure performed was ovarian cystectomy. The most common histopathological finding was functional ovarian cyst. Only $3.1 \%$ of cases needed conversion to laparotomy for the completion of the procedure. Complication rate was minimal.

Conclusions: Laparoscopy due to its lesser adverse effects, less postoperative pain, shorter stay in hospital, small erre-admission rates, better panoramic vision is considered more beneficial than laparotomy. Careful patient selection and availability of a experts should be taken into account. The current study is an over view of our experience in favor of laparoscopy in treatment of a large population of women with benign adnexal masses.
\end{abstract}

Keywords: Adnexal mass, Laparoscopy, Ovarian Cystectomy

\section{INTRODUCTION}

Over years, laparoscopy has evolved from a limited gynecologic surgical procedure used only for diagnosis and tubal ligations to a major surgical tool used for management of a variety of gynecological conditions. Today, laparoscopy has emerged as one of the most common surgical procedures. The faster recovery time, minimal pain, fewer days of hospitalization and better aesthetic results has made laparoscopy immensely popular. Also, technical parameters such as the magnified view during the procedure and relatively small risk of complications resulted in the wide use of laparoscopic surgery in gynecology. Laparoscopy has now become the gold standard method for management of a wide range of gynecological ailments, including the adnexal masses. Although, most of the adnexal masses arise from ovaries, a wide variety of pathologies may be associated. Tuboovarian abscess, ectopic pregnancy, subserosal fibroids with pedicle, appendicular mass etc are the common pathologies that need to be differentiated. ${ }^{1} \mathrm{~A}$ number of non-neoplastic and neoplastic lesions occur within the ovaries. They can present from the neonatal period to post-menopause. Most are functional in nature and resolve with minimal treatment. However, ovarian cysts can herald an underlying malignant process. When cysts are large, persistent, or painful, surgery may be required. $^{2}$ The sonological detection of ovarian 
malignancy is quite good and acceptable. The predictive value is about $96 \%$ in detection of the benign masses. ${ }^{3}$ The procedure, being non-invasive, is widely acceptable for establishing the diagnosis. Magnetic resonance imaging (MRI) increases the specificity of imaging evaluation for adnexal masses, especially when they are indeterminate on ultrasound. ${ }^{4}$ MRI has a high accuracy in differentiating benign from malignant masses. Endometriomas, Teratomas, simple cysts, fibromas, exophytic or extrauterine fibroids, and hydrosalpinges can be diagnosed with high specificity. Histopathological and MRI correlation of adnexal masses, the role of MRI in the differentiation of benign from malignant adnexal pathologies, is found to quite promising. Magnetic resonance imaging is useful in characterization of adnexal masses that are not completely evaluated by ultrasound. It can provide valuable information on soft tissue composition based on specific tissue relaxation times and allows multiplanar imaging at large field of view to define the origin and extent of pelvic pathology. ${ }^{5}$

\section{METHODS}

This is a prospective study of 7 months, from July 2017 to January 2018, conducted in the Dept of Obstetrics and Gynecology, MGM Medical College and M.Y. Hospitals Indore, MP. During this period, 63 patients underwent laparoscopy for various types of adnexal masses. All cases were operated on elective basis.

Detailed history, a thorough general physical examination and pre-anesthetic work-up was done on all patients. Inclusion criteria were benign mass (Transvaginal ultrasound finding), preoperative estimation of the tumor markers levels especially CA 125 (normal range 0-35 $\mathrm{mU} / \mathrm{L}$ ), unruptured ectopic pregnancy. In cases of doubt, MRI with or without contrast was done to establish the exact nature of the masses (Eltabbakh GH et al). ${ }^{1}$ Exclusion criteria were known contraindications for laparoscopy, such as high BMI or medical reasons, ultrasonographic evidence of malignancy and exceptionally high preoperative $\mathrm{Ca} 125$ values (more than $200 \mathrm{U} / \mathrm{ml})^{2}$ Levels below $35 \mathrm{U} / \mathrm{mL}$ were considered normal. ${ }^{3}$ Large (more than $12 / 12 \mathrm{~cm}$ ) solid, fixed or irregular adnexal masses suspicious of malignancy were treated by laparotomy. Trans-vaginal ultrasound scanning was used as primary imaging (Matsushita $\mathrm{H}$ et al). ${ }^{2}$ After written informed consents, all the patients were taken for the procedures under general anesthesia. Preoperative findings were noted. All patients underwent careful bowel preparations. Assessment of indications, intraoperative findings and various interventions done during the procedures were carefully analyzed. As a standard protocol, in almost all cases the specimen was taken out by post colpotomy. In a few cases, where the size of the specimen is small, it was taken out through one of the side ports. The facility of frozen section biopsy is not available in our centre. All the specimens were sent for histopathological examinations post operatively. All the patients received single dose IV ceftriaxone and sulbactum (1.5 gm) preoperatively and 3 days oral antibiotic (200 mg cefixime) for next 5 days, except in complicated cases. In complicated cases, they were individualized for antibiotic protocol. Study was approved by the ethical committee of the institution.

\section{RESULTS}

Maximum patients were from the age group 26-30 yrs. The average operating time was 75 mints. The average intra-operative blood loss was $130 \mathrm{ml}$. The average hospital stay was 2 days. Total $12.6 \%$ (8) cases needed conversion into laparotomy.

Table 1: Histopathology of the adnexal masses.

\begin{tabular}{|lll|}
\hline Types & Nos & Percentage \\
\hline Functional (follicular/CL cysts) & 17 & 26.9 \\
\hline Chocolate cysts & 15 & 23.8 \\
\hline Dermoids & 7 & 11.1 \\
\hline Serous cystadenoma & 7 & 11.1 \\
\hline Unruputed ectopic pregnancy & 7 & 11.1 \\
\hline $\begin{array}{l}\text { Torsion ovary (signs of } \\
\text { gangrene) }\end{array}$ & 4 & 6.3 \\
\hline Pyosalpingx & 2 & 3.1 \\
\hline Mucinous cystadenoma & 2 & 3.1 \\
\hline Para ovarian cysts & 2 & 3.1 \\
\hline
\end{tabular}

The most common histopathological findings of in this study was follicular ovarian cyst $(26.9 \%)$ followed by chocolate cysts $(23.8 \%)$. Dermoids were found in relative younger females in about $11.1 \%$ cases.6.3\% of the cases were of torsion ovary with signs of gangrene. There were $3.1 \%$ rare cases of parovarian tumours (Table 1 ).

Table 2: Type of operations for adnexal masses.

\begin{tabular}{|c|c|c|}
\hline Procedure proper & Nos & Percentage \\
\hline Ovarian cystectomy & 26 & 41.2 \\
\hline $\begin{array}{l}\text { Aspiration and cyst wall } \\
\text { dissection }\end{array}$ & 19 & 30.1 \\
\hline Ovarian drilling/puncture & 16 & 25.3 \\
\hline Adhesiolysis & 13 & 20.6 \\
\hline $\begin{array}{l}\text { Cautery/fulguration for } \\
\text { endometriotic lesions }\end{array}$ & 12 & 19.0 \\
\hline Salpingectomy & 8 & 12.6 \\
\hline Salpingopherectomy & 7 & 11.1 \\
\hline Conversion to laparotomy & 2 & 3.1 \\
\hline $\begin{array}{l}\text { Excision of paraovarian } \\
\text { cyst/removal from B/L }\end{array}$ & 2 & 3.1 \\
\hline
\end{tabular}

The most common surgery carried out in this study is ovarian cystectomy (41.2\%). In maximum cases of chocolate cysts; we were able to do excision of the cyst. Only in a few small, thin walled endometriomas, aspiration and de-roofing of the cyst wall was done. Rest superficial endometriotic spots were fulgurated or cauterized (19\%). Functional cysts were aspirated and cyst walls were dissected $(30.1 \%)$. In, $25.3 \%$ cases, 
ovaries appeared bulky and polycystic as such drilling of ovaries in multiple sites was done with unipolar cautery. Salpingectomy was done in $12.6 \%$ cases. In all the cases of pyosalpinx and ectopic pregnancies, this was carried out as the standard procedure. In only one case of chocolate cyst, unilateral Salpingectomy was done along with cystectomy, as the tube of that side was irreparably damaged, keeping in view the possibility of future IVF. Salpingopherectomy was done in $11.1 \%$ cases. In all the cases of torsion ovary, Salpingopherectomy was done. In 2 cases of ectopic pregnancy, Salpingopherectomy was done; as the ovaries were inseparably adhered to the tubes.3.1\% (2) cases have to be converted to laparotomy due to uncontrollable bleeding and dense (1case), adhesions due to deep endometriosis (1case). Rest 3.1\% cases of para ovarian cysts, excision of cyst was carried out after opening the broad ligaments (Table 2).

Table 3: Complications.

\begin{tabular}{|lcl|}
\hline $\begin{array}{l}\text { Type of } \\
\text { complications }\end{array}$ & $\begin{array}{l}\text { No. of } \\
\text { cases }\end{array}$ & $\begin{array}{l}\text { Outcome } \\
\text { IV Antibiotics for } 3\end{array}$ \\
$\begin{array}{l}\text { Post-operative } \\
\text { fever }\end{array}$ & $3(4.7 \%)$ & $\begin{array}{l}\text { lays. } \\
\text { days }\end{array}$ \\
$\begin{array}{l}\text { Post-operative } \\
\text { pneumonia }\end{array}$ & $2(3.1 \%)$ & $\begin{array}{l}\text { Conservative } \\
\text { management in ICU } \\
\text { for } 24 \text { hrs. }\end{array}$ \\
$\begin{array}{l}\text { Post-operative } \\
\text { entry site wound } \\
\text { infection }\end{array}$ & $2(3.1 \%)$ & $\begin{array}{l}\text { Dressing on OPD basis } \\
\text { and antibiotics. }\end{array}$ \\
\hline $\begin{array}{l}\text { Post-operative } \\
\text { urinary retention }\end{array}$ & $1(1.5 \%)$ & $\begin{array}{l}\text { Combination antibiotics, } \\
\text { Catheterization for a } \\
\text { week followed by } \\
\text { removal after clamping } \\
\text { and declamping and } \\
\text { long term antibiotic } \\
\text { prophylaxis against UTI } \\
\text { Conversion to }\end{array}$ \\
\hline $\begin{array}{l}\text { Intra-operative } \\
\text { bleeding }\end{array}$ & $1(1.5 \%)$ & $\begin{array}{l}\text { laparotomy and post- } \\
\text { operative blood } \\
\text { transfusion }\end{array}$ \\
\hline
\end{tabular}

There were no major complications in the study. The most common complication was post-operative fever $(4.7 \%)$. Pneumonia was an important post-operative anaesthetic complication that occurred in $3.1 \%$ of the cases (Table 3).

\section{DISCUSSION}

This study tried to assess the status of the laparoscopic approach to primarily benign ovarian tumors and other adnexal masses. For ruling out malignancy, we followed standard protocol and is comparable to the other authors Herrmann U et al and Jacobs I et al. ${ }^{6,7}$

In our study, the maximum patients were between age group 26-30 yrs. In a comparable study of Lt ColBS Duggal et al, the mean age was 33 yrs. $^{8}$ In present study; we had included 2 cases of patients aged $15 \mathrm{yrs}$ with dermoid cysts. As such, our study was conducted in a relatively younger group of patients.

The average operating time in our study was 75 mints. It is comparable to the study conducted by $\mathrm{Lt} \mathrm{Col} \mathrm{BS}$ Duggal et al. ${ }^{8}$ In their study, the average operating time was 70 mints. This is to be mentioned here that due to good interdepartmental coordination, the operating time was quite comparable to other studies, even in difficult cases.

The average intra-operative blood loss was $130 \mathrm{ml}$ in our study, as opposed to the study of Lt Col BS Duggal et al, where the mean blood loss was $155 \mathrm{ml}^{8}{ }^{8}$ Use of vessel sealer in all of our cases significantly reduced the amount of intra-operative blood loss.

$3.1 \%$ of cases needed conversion to laparotomy to complete the procedure. This was significantly high $(19 \%)$ in the study of Serur E et al. ${ }^{9}$ It was $8 \%$ in Grammatikakis I et al study. ${ }^{4}$ This need was significantly lower in our study because of the stringent selection of cases. Also, the malignant cases were excluded from our study.

The most common histopathological findings of in our study was follicular ovarian cyst $(26.9 \%)$ followed by chocolate cysts $(23.8 \%)$. It is comparable to the study of Lt Col BS Duggal et al. ${ }^{6}$ They also reported that most of the cases were Ovarian cyst and Endometriotic cysts. Eli Serur E et al also found that that most important pathology was serous cyst. ${ }^{9}$ This is due to the fact that Serouscystadenoma is the most common benign tumor of ovaries (Zaman S et al). ${ }^{1}$

Most common surgical procedure done in our study is ovarian cystectomy (41.2\%) followed by Aspiration and Cyst wall dissection (30.1\%). Ovarian drilling/Puncture $(25.3 \%)$ and Adhesiolysis (20.6\%) were the most common adjuvant additional procedures done. Most common procedure was cystectomy $(62 \%)$ in the study of Lt Col BS Duggal. ${ }^{8}$ Ovarian cystectomy is the method of choice in young patients to preserve fertility. Present study constitutes mostly of young females, as just this procedure was preferentially done in many patients.

Although there was no major complication in our study, complications did occur in about $5 \%$ cases. Most dreaded one was post operative pneumonia in $3.1 \%$ cases. They required ICU care, hospitalization for 5 days and prolonged antibiotic treatment. $1.5 \%$ had post operative urinary retention. She required catheterization for extended period of time and antibiotics. $10 \%$ complication rate was seen in the study of Eli Serur et al. ${ }^{9}$ Grammatikakis et al had overall complication rate of $11.3 \%$. Post-op fever, small hematomas at the Trocar entry points were the main complications of his study. ${ }^{4}$ Our complication rates were less or at least comparable to 
the similar studies due to careful selection of the cases and easy availability of the expert hands (Herendael VB). ${ }^{5}$

\section{CONCLUSION}

The discovery of adnexal masses is an important which may affect females of all age groups. Majority of them $r$ diagnosed incidentally. Some of these, may undergo torsion or rupture. They may also pose significant diagnostic and management dilemmas. The laparoscopic approach is effective and safe for managing patients with adnexal masses of unknown pathology. Adequate surgical skills along with good histopathological reporting are required for successful operative management. Proper selection of cases, multidisciplinary team approach and expert laparoscopic surgical team are imperative for good patient outcome.

Funding: No funding sources Conflict of interest: None declared

Ethical approval: The study was approved by the Institutional Ethics Committee

\section{REFERENCES}

1. Zaman S, Majid S, Hussain M, Chughtai O, Mahboob J, Chughtai S. A retrospective study of ovarian tumours and tumour-like lesions. J Ayub Med Coll Abbottabad. 2010 Jan-Mar; 22(1):104-8.

2. Matsushita H, Watanabe K, Yokoi T, Wakatsuki A. Unexpected ovarian malignancy following laparoscopic excision of adnexal masses. Human Reprod. 2014 Jun 25;29(9):1912-7.
3. Karnik A, Tembey RA, Mani S. Value of MRI in characterizing adnexal masses. J Obstet Gynecol India. $2015 \mathrm{Jul}$;65(4):259-66.

4. Grammatikakis I, Trompoukis P, Zervoudis S, Mavrelos C, Economides P, Tziortzioti V et al. Laparoscopic treatment of 1522 adnexal masses: an 8-year experience. Diagnos Therapeu Endosc. $2015 ; 2015$.

5. Van Herendael B, Beretta P, Slangen T, Franchi M, Swaegers M, Zanaboni F. Management of adnexal masses by operative laparoscopy. J Am Assoc Gynecol Laparosc. 1995;2(3):273-7.

6. Herrmann JU, Locher GW, Goldhirsch A. Sonographic patterns of ovarian tumors: prediction of malignancy. Obstet Gynecol. 1987 May;69(5):777-81.

7. Jacobs I, Bast R. The CA-125 tumour associated antigen: a review of the literature. Hum Reprod. 1989;4:1.

8. Duggal BS, Tarneja P, Sharma RK, Rath SK, Wadhwa RD. Laparoscopic management of adnexal masses. Med J Armed Forces India. 2004 Jan $1 ; 60(1): 28-30$.

9. Serur E, Emeney PL, Byrne DW. Laparoscopic management of adnexal masses. JSLS. 2001 Apr;5(2):143-151.

Cite this article as: Bhattacharjee $S$, Sharma $S$. Laparoscopic management of adnexal masses: a hospital-based study. Int J Reprod Contracept Obstet Gynecol 2018;7:1427-30. 